(International Journal of Agriculture and Wildlife Science)
http://dergipark.org.tr/ijaws

Araştırma Makalesi

\title{
Gümüşhane Ekolojik Koşullarında Bazı Altı Sıralı Arpa Çeşitlerinin Tane Kalite Özellikleri ve Besin Değerlerinin Belirlenmesi
}

\author{
Abdulveli Sirat $^{1 *}, \quad$ Bilge Bahar $^{2}$ \\ ${ }^{1}$ Gümüşhane Üniversitesi, Şiran Mustafa Beyaz Meslek Yüksek Okulu, Gümüşhane \\ ${ }^{2}$ Gümüşhane Üniversitesi, Mühendislik ve Doğa Bilimleri Fakültesi, Gıda Mühendisliği Bölümü, Gümüşhane \\ Geliş tarihi (Received): 02.02.2020 Kabul tarihi (Accepted): 07.03.2020
}

\begin{abstract}
Anahtar kelimeler:
Arpa, çeşit, kalite, ADF, NDF, mineral madde

awsirat@hotmail.com

Özet. Bu araştırma, 2012-2013 ve 2013-2014 yetiştirme dönemlerinde 11 farklı altı sıralı arpa çeşidinin (Erginel-90, Meriç, Kıral-97, Çetin-2000, Avcı-2002, Martı, Vamıkhoca-98, Akhisar-98, Lord, Epona ve Olgun) bazı tane kalite özelliklerini (nem oranı, kül oranı, protein oranı, yağ oranı, nişasta içeriği, asit deterjanda çözünmeyen lif (ADF), nötr deterjanda çözünmeyen lif (NDF) ve çeşitli mineral madde içeriklerini $(K, M g, P)$ ) belirlemek için Gümüşhane koşullarında, Tesadüf Blokları Deneme Desenine göre üç tekrarlamalı olarak yürütülmüştür. İki yılın ortalamasına göre çeşitlerin nem oranı \%9.21-9.88, kül oranı \%2.00-2.31, protein oranı \%12.73-15.65, yağ oranı \%1.36-2.01, nişasta içeriği \%52.61-58.60, ADF ve NDF değerleri sırasıyla \%5.52-8.65 ile \%20.42-25.03 arasında değişmiştir. En yüksek nişasta oranı Olgun çeşidinden (\%58.60) elde edilmiştir. En yüksek protein oranına (\%15.65) ise Akhisar-98 çeşidi sahip olmuştur.
\end{abstract}

\section{Determination of Grain Quality Traits and Nutritional Values of Some Six Rowed Barley Cultivars Under the Ecological Conditions of Gumushane}

\section{Keywords:}

Barley, cultivar, quality, ADF, NDF, mineral matter

\begin{abstract}
This research was carried out with 11 different six rowed barley cultivars (Erginel-90, Meriç, Kıral-97, Çetin-2000, Avcı-2002, Martı, Vamıkhoca-98, Akhisar-98, Lord, Epona and Olgun) during 2012-2013 and 2013-2014 growth seasons to determine some grain quality traits such as moisture content, ash content, protein content, fat content, starch content, acid detergent insoluble fiber (ADF), neutral detergent insoluble fiber (NDF) and various mineral matter contents ( $\mathrm{K}, \mathrm{Mg}, \mathrm{P})$ under Gumushane conditions with randomized block design as three replicated. According to the average of two years, the moisture content of the cultivars were $9.21-9.88 \%$, ash content was $2.00-2.31 \%$, protein content was $12.73-15.65 \%$, fat content was 1.36-2.01\%, starch content was $52.61-58.60 \%$, ADF and NDF values respectively $5.52-8.65 \%$ to $20.42-25.03 \%$, ranged between. The highest starch ratio was obtained from Olgun cultivar (58.60\%). Akhisar-98 cultivar had the highest protein content (15.65\%).
\end{abstract}




\section{GíRiş}

Günlük ekmeğin hammaddesi olan tahıllar, insan beslenmesinde ayrıca endüstride ve hayvan beslemede yaygın olarak kullanılmaktadır. Arpa, günümüzde hayvan yemi (dane ve saman) olarak, bira yapımında ve az da olsa bazı ülkelerde insan beslenmesinde kullanılan tahıllardan biridir. Besin açısından yem değeri, mısırın \%95'i kadar olan arpa, dünyada ekimi \%65 oranında hayvan yemi olarak, maltık bira ve viski ham maddesi olarak \%33 ve gıda sanayinde \%2'si insan beslenmesinde değerlendirilmektedir. Türkiye'de ise tüketimin \%90'ı hayvan yemi, diğer kısmı ise maltlık olarak bira sanayinde ve gıda endüstrisinde kullanılmaktadır. Gıda sanayisinde arpa kullanımı oranı çok düşük olsa da son yıllarda giderek artmaktadır (Alkan ve Kandemir, 2015). Bazı ülkelerde arpa ununun, buğday unu içerisine karıştırılarak kullanıldığı da bilinmektedir.

Arpa tanesinin farklı mineraller bakımından çok zengin olduğu ve bu minerallerin hayvanlar açısından da önemli işlevlere sahip oldukları eskiden beri bilinmektedir. Bunun için hayvan beslemede de yoğun olarak kullanılmaktadır (Sönmez ve Yılmaz, 2000). Tane kalitesi düşünüldüğünde; proteinler, karbonhidratlar ve yağlar gibi organik bileşikler ile fosfor, kalsiyum, potasyum, magnezyum ve mikro besin elementleri bakımından zengin olan tane akla gelmektedir (Guo ve ark., 2003). Arpa tanesi genotiplere göre değişkenlikle birlikte yaklaşık \%6575 nişasta, \%8-15 protein, \%1-5 yağ, \%1.5-3.0 şeker, \%1.0-2.5 kül, \%11-13 nem, \%5 selüloz ve diğer mineraller (kalsiyum, fosfor, potasyum), vitaminler (A, B ve E) içeriği ile hayvanların beslenmesinde hayati bir öneme sahiptir. Hayvan yemi olarak yaygın biçimde kullanılan arpa, içerdiği farklı mineral ve vitaminler ile özellikle besin kaynağı konumunda değer kazanmıştır (Kün, 1996; Sencar ve ark., 1997; Bekele ve ark., 2005). Arpanın kimyasal yapısına, genetik farklılıkların etki ettiği ve çeşitli genotipler arasında değişen oranlarda mineral maddelerin olduğu önceki çalışmalarda araştırmacılar tarafından rapor edilmiştir (Guo ve ark., 2003). Arpanın kül oranı genellikle, \%1.3-2.5 arasında farklıık gösterip, ince kabuklu ve dolgun taneli arpa çeşitlerinde bu oran daha da düşüktür (Özer ve ark., 2003). Campbell ve ark. (1995), arpa tanesinin sindirilebilirliğine ve metabolik enerji içeriğine katkıda bulunan kimyasal maddeler arasında; yağ, nişasta ve hücre duvarındaki yapısal karbonhidratların (selüloz, hemiselüloz, lignin, pektin, $\beta$-glukan ve galaktan) yer aldığını belirtmiştir. Asit deterjanda çözünmeyen lif (ADF), bitki hücre duvarı yapısındaki selüloz, lignin ve çözünmeyen protein miktarını göstermekte, ayrıca yemin sindirilebilirliği ve hayvanın enerji alımı hakkında da bilgi vermektedir. Yüksek asit deterjanda çözünmeyen lif içeren yemlerin sindirilebilirliği ve enerji değeri düşüktür (Kutlu, 2008). Bitki hücre duvarı yapısında bulunan selüloz, hemiselüloz, lignin, kütin ve çözünmeyen protein miktarı NDF (Nötr deterjanda çözünmeyen lif) olarak ifade edilmektedir. Nötr deterjanda çözünmeyen lif (NDF) değeri hayvanların beslenmesinde doğrudan etkili olup, yemin içeriğindeki bu değer azaldıkça hayvanın beslenmesi daha artmaktadır (Van Soest ve ark., 1991; Mut ve ark., 2017).

Araştırmada, 11 farklı altı sıralı arpa çeşidi ile yürütülen denemeden elde edilen bazı tane kalite kriterleri ve besleme değerlerine ilişkin veriler değerlendirilmiştir. Bu çalışmanın amacı, kaliteli yemlik (altı sıralı) arpa çeşitlerinin belirlenerek, yöreye uygun çeşitlerin üreticilerin hizmetine sunulabilmesidir.

\section{MATERYAL VE METOT}

Araştırma, Doğu Karadeniz Bölgesi, Gümüşhane Illi, Şiran ilçesi çifţ̧i tarlasında 2 yıl süreyle (2012-13 ve 201314) yürütülmüştür. Araştırmada değişik kuruluşlar tarafından geliştirilen toplam 11 adet 6 sıralı arpa çeşidi kullanılmıştır. Çeşitler ve tescil edildiği kuruluşlar, Çizelge 1'de verilmiştir.

Çizelge 1. Denemede kullanılan arpa çeşitlerine ait bazı bilgiler.

Table 1. Some information about barley varieties used in the experiment.

\begin{tabular}{clcl}
\hline S. No & Çeşit & Tescil yılı & \multicolumn{1}{c}{ Tescil edilen kuruluş } \\
\hline 1 & Erginel-90 & 1990 & Anadolu Tarımsal Araştırma Enstitüsü-ESKişEHiR \\
2 & Meriç & 2005 & Anadolu Efes Biracılı ve Malt San. A.Ş. KONYA \\
3 & Kıral-97 & 1997 & Bahri Dağdaş Uluslararası Tar. Araş. Enst.-KONYA \\
4 & Çetin-2000 & 2000 & Tarla Bitkileri Merkez Araştırma Enstitüsü-ANKARA \\
5 & Avcı-2002 & 2002 & Tarla Bitkileri Merkez Araştırma Enstitüsü-ANKARA \\
6 & Martı & - & Trakya Tarımsal Araştırma Enstitüsü-EDiRNE \\
7 & Vamıkhoca-98 & 1998 & Ege Tarımsal Araştırma Enstitüsü-İzmir \\
8 & Akhisar-98 & 1998 & Ege Tarımsal Araştırma Enstitüsü-İzmir \\
9 & Lord & - & Tareks Tar. Ürün. Araç. Ger. İth. İhr. ve Tic. A.Ş. ANKARA \\
10 & Epona & 2004 & Genç Toh. Üret. Araş. Tur. San. ve Tic.Ltd.Şti. TEKIRDAĞ \\
11 & Olgun & 2011 & Doğu Anadolu Tarımsal Araştırma Enstitüsü-ERZURUM \\
\hline
\end{tabular}


Denemelerin yürütüldüğü topraklar ilk yıl, killi-tınlı, pH'sının hafif alkali (7.99), orta derecede kireçli (\%10.66), hafif tuzlu (\%0.15), organik madde bakımından az (\%1.63), fosfor bakımından çok az (1.95 kg da-1), potasyum bakımından ise yeterli $\left(149.1 \mathrm{~kg} \mathrm{da}^{-1}\right)$ bir bünyeye sahip olup; ikinci yılın toprak yapısı ise killi tınlı (\%62.0), organik maddece orta (\%2.41), orta derecede fosfor $\left(6.13 \mathrm{~kg} \mathrm{da}^{-1}\right)$ içerikli, potasyum bakımından yeterli, çok fazla kireçli (\%25.56), tuzsuz ve alkali bir yapıdadır.

Denemenin yürütüldüğü yerlere ait iklim verileri, Meteoroloji Genel Müdürlüğü, Gümüşhane Meteoroloji Bölge Müdürlüğü kayıtlarından elde edilmiştir. Gümüşhane ilinin uzun yıllar ortalaması (1950-2014) ile çalışmanın yapıldığı 2012-2014 yıllarına ait iklim değerleri arpanın yetişme dönemi dikkate alınarak Çizelge 2'de verilmiştir. Çizelgeden görüldüğü üzere, yağışların denemenin birinci yılında, ikinci yılı ve uzun yıllar ortalamasına göre çok yüksek olduğu kaydedilmiştir. Düşen yağış miktarı denemenin birinci yılında 436.8 mm, ikinci yılında $330.1 \mathrm{~mm}$ olmuşken, uzun yıllar ortalaması da $416.1 \mathrm{~mm}$ olarak rapor edilmiştir. 2012-2013 yetiştirme periyodunda uzun yıllar ortalamasına kıyasla daha yüksek, 2013-2014 yetiştirme döneminde ise daha düşük yağış gerçekleşmiştir. Denemenin ikinci yılı olan Nisan ayının üçüncü haftasında görülen şiddetli dondan dolayı bitkiler zarar görmüştür.

Denemede kullanılan tohumlar, ekim sıklı̆ı $\mathrm{m}^{2 \prime}$ de 500 adet tohum düşecek şekilde, ekimler parsel ekim mibzeri ile 5 m uzunluğunda, sıra arası mesafe 20 cm 6 sıra olarak; ilk yıl 19 Eylül 2012 tarihinde, ikinci yıl ise 05 Ekim 2013 tarihinde ekilmiştir.

Çizelge 2. Gümüşhane iline ait 2012-2014 yılları arası ve uzun yıllar ortalaması iklim verileri.

Table 2. The climate values for long term average and between 2012 to 2014 in Gümüşhane province.

\begin{tabular}{lccccccccc}
\hline \multirow{3}{*}{ AYLAR } & \multicolumn{3}{c}{ Ortalama sıcaklık ( $\left.{ }^{\circ} \mathbf{C}\right)$} & \multicolumn{3}{c}{ Toplam yağış $(\mathbf{m m})$} & \multicolumn{3}{c}{ Ortalama nem (\%) } \\
\cline { 2 - 9 } & $\mathbf{2 0 1 2 -}$ & $\mathbf{2 0 1 3 -}$ & Uzun & $\mathbf{2 0 1 2 -}$ & $\mathbf{2 0 1 3 -}$ & Uzun & $\mathbf{2 0 1 2 -}$ & $\mathbf{2 0 1 3 -}$ & Uzun \\
& $\mathbf{2 0 1 3}$ & $\mathbf{2 0 1 4}$ & Yıl. & $\mathbf{2 0 1 3}$ & $\mathbf{2 0 1 4}$ & Yıl. & $\mathbf{2 0 1 3}$ & $\mathbf{2 0 1 4}$ & Yıl. \\
\hline Ekim & 15.2 & 12.3 & 11.4 & 31.2 & 28.2 & 42.3 & 59.2 & 53.5 & 62.0 \\
Kasım & 8.3 & 8.7 & 5.1 & 35.7 & 19.6 & 41.3 & 68.1 & 63.4 & 66.7 \\
Aralık & 2.4 & -2.2 & 0.5 & 68.3 & 31.3 & 39.4 & 68.5 & 65.0 & 68.2 \\
Ocak & -0.1 & 2.1 & -1.7 & 47.9 & 28.5 & 35.1 & 66.7 & 62.9 & 66.9 \\
Subat & 3.9 & 3.3 & -0.5 & 57.7 & 22.1 & 32.4 & 63.6 & 54.3 & 64.2 \\
Mart & 7.1 & 8.9 & 3.7 & 66.5 & 45.3 & 41.7 & 54.7 & 55.7 & 62.0 \\
Nisan & 12.5 & 13.5 & 9.4 & 47.9 & 38.1 & 60.0 & 55.2 & 53.8 & 60.2 \\
Mayıs & 17.8 & 17.1 & 13.7 & 19.9 & 66.7 & 66.4 & 49.0 & 58.5 & 60.8 \\
Haziran & 20.2 & 20.8 & 17.2 & 52.1 & 31.0 & 44.8 & 51.9 & 51.5 & 59.8 \\
Temmuz & 21.0 & 26.0 & 20.2 & 9.6 & 19.3 & 12.7 & 52.6 & 48.7 & 58.5 \\
\hline Top./Ort & 10.83 & 11.05 & 7.90 & 436.8 & 330.1 & 416.1 & 58.95 & 56.73 & 62.93 \\
\hline
\end{tabular}

Araştırmalar Tesadüf Blokları Deneme Deseninde 3 tekrarlı olarak yürütülmüştür. Denemelerde, dekara saf 10 $\mathrm{kg} \mathrm{N}$ ve $6 \mathrm{~kg} \mathrm{P}_{2} \mathrm{O}_{5}$ hesabıyla gübre verilmiştir. Fosforlu gübrenin tamamı ekimle birlikte, azotlu gübrenin yarısı ekimle, diğer yarısı ise sapa kalkma dönemi öncesinde uygulanmıştır. Yabancı otlarla kültürel (el çapası ile) mücadele iki aşamada (bitkilerin çıkışından sonra ve kardeşlenme döneminde) gerçekleşmiştir. Hasatlar her iki yııın Temmuz ayının üçüncü haftasında (1. yıl 23.07.2013, 2. yıl 18.07.2014), başakların tam olgunlaştığı dönemde parsel kenarlarından 1'er sıra ve parsel başlarından 0,50'er metre atılarak geri kalan $\left(0.95 \times 4.0=3.8 \mathrm{~m}^{2}\right.$ lik alan) kısım orakla yapılmıştır. Araştırmada kullanılan örnekler (arpa tanesi) değirmende öğütülüp, analize hazır hale getirilerek nem, kül, protein ve yağ oranı, nişasta içeriği, $K, M g, P$, asit deterjanda çözünen lif (ADF) ve nötr deterjanda çözünen lif (NDF) değerleri incelenmiştir. Kül, yağ ve protein oranı ölçüm ve analizleri Elgün ve ark. (2001)'na göre yapılmıştır. Asit deterjanda çözünen lif (ADF) ve nötr deterjanda çözünen lif (NDF) değerleri, Van Soest ve ark. (1991)'nın yöntemine göre belirlenmiştir. Araştırmadan elde edilen sonuçlar, JMP 7.0.2 istatistik paket programı kullanılarak, Tesadüf Blokları Deneme Desenine göre analiz edilmiştir (JMP, 2007). Çeşitler arasındaki etkili farklııkları görmek için $F$ testi kullanılmak suretiyle $P$ olasılık değerleri saptanmış; ortalama değerler arasındaki karşılaştırmalar, LSD testine göre değerlendirilerek gruplandırma yapılmıştır.

\section{BULGULAR VE TARTIŞMA}

2012-13 ve 2013-14 yetiştirme mevsimlerinde denemeye alınan 11 adet altı sıralı arpa çeşidinde incelenen özelliklere ilişkin varyans analiz sonuçları Çizelge 3 ve $6^{\prime}$ da verilmiş olup; kül oranı, protein oranı, yağ oranı, nişasta içeriği, K, Mg, P, ADF ve NDF gibi özellikler çeşit bakımından farklılıklar gösterirken; nem oranı ise çeşit ve yıl ×çeşit interaksiyonu bakımından değişim göstermiştir. 


\section{Nem Oranı}

Denemede yer alan çeşitlere ait değerlerin 2 yıllık ortalamasının \%9.21-9.88 arasında değiştiği tespit edilmiştir. En yüksek nem oranı \%9.88 ile Martı çeşitten elde edilirken, bunu Akhisar-98 (\%9.80) ve Olgun (\%9.76) çeşitleri takip etmişlerdir. En düşük nem oranı ise Kıral-97 (\%9.21), Avcı-2002 (\%9.26), Çetin-2000 (\%9.27) ve Erginel-90 (\%9.28) çeşitlerden elde edilmiştir (Çizelge 4). Nem oranının düşüklüğü, arpada kalitenin yüksek olması demektir. Ülkemizde arpa tanelerinin nem oranı genellikle \%9-13 arasında değişmektedir (Çölkesen, 1993; Kün, 1996). Nem oranı, tahıl ticareti ve depolanması açısından çok önemli bir faktördür. Arpa tanesinde bulunan nem miktarı, yetiştiği yerdeki iklim koşullarına, hasat mevsiminde yağış veya olgunluk süresinin kısalığına, depolama yöntemine, depolama yerinin nispi neminin ve sıcaklığının yükselmesine bağlı olarak değişmektedir. Arpalarda nem oranının çok düşük olması da istenmez. Çok kuru arpa gevrek olur, taşımada kolaylıkla kırılmakta, kırık tane de yabancı maddeden sayılmaktadır (Çölkesen, 1993; Kün, 1996; Sencar ve ark., 1997).

\section{Kül Oranı}

Arpa tanesindeki kuru maddenin önemli bir bölümünü organik maddeler, geri kalan kısmını ise inorganik maddeler oluşturmaktadır. Kuru madde, doğru ve uygun bir şekilde yakıldığında geriye kalan yanmamış maddelerin tamamına "ham kül" adı verilmektedir (Kutlu, 2008). Ham kül oranı tanenin mineral içeriği ile yakından ilişkilidir. Çünkü arpa külünün mineral içeriği temel olarak potasyum ve fosfordan oluşmakta, az miktarda ise klor, magnezyum, kükürt, sodyum ve kalsiyum teşkil etmektedir. Arpa tanesinin külünde bu maddelerin haricinde demir, çinko, bakır, manganez ve selenyum gibi daha az miktarda minerallerde bulunmaktadır (Alkan ve Kandemir, 2015). Çalışmada, 2 yılın ortalamasına göre çeşitlerin kül oranı \%2.00-2.31 arasında değişmiştir. Kül oranı Kıral-97 (\%2.31) çeşidinde daha yüksek olmakla birlikte Martı (\%2.27), Vamıkhoca-98 (\%2.24), Avcı-2002 (\%2.20), Akhisar98 (\%2.24) ve Epona (\%2.17) çeşitleri istatistiki olarak aynı grupta yer almıştır (Çizelge 4). İklimsel faktörlerden dolayı denemedeki arpa çeşitlerinin farklı yıllardaki kül oranlarında değişimler gözlemlenmiştir. Özer ve ark. (2003), kül miktarının genellikle, \%1.3-2.5 arasında değiştiğini; ince kabuklu ve dolgun taneli çeşitlerin kül oranının daha düşük olduğunu bildirmişlerdir. Ayrıca, yüksek sıcaklık ve su stresi sebebi ile danede bulunan kül miktarının arttığı bildirilmiştir (Öztürk ve Aydın, 2004; Egesel ve ark., 2009). Kül miktarı arpanın çeşidine, yetiştirildiği iklim ve çevre faktörlerine bağlı olarak değişmektedir. Bazı araştırmacılar yaptıkları çalışmalarda, kül oranının çeşitlere göre değişkenlik gösterdiğini rapor etmişlerdir (Ünal, 1991; Grausgruber ve ark., 2000; Özer ve ark., 2003; Ereifej ve ark., 2007; Egesel ve ark., 2009; Anjum ve ark., 2014; Mahla ve ark., 2015).

\section{Protein Orant}

Protein oranı açısından çeşitlere ait ortalama değerler arasındaki farklar 2 yılın ortalamasına göre istatistiksel olarak $\mathrm{P} \leq 0.01$ seviyesinde önemli bulunmuştur (Çizelge 3,4 ). Denemede yer alan çeşitlere ait protein değerlerinin 2 yıllık ortalaması \%12.73-15.65 arasında değişmiştir. En yüksek protein oranı \%15.65 ile Akhisar-98 çeşitten elde edilirken, bu çeşidi Epona (\%15.61), Martı (\%15.27) ve Avcı-2002 (\%15.26) çeşitleri takip etmiştir. En düşük protein oranı ise, Olgun (\%12.73) ve Kıral-97 (\%12.78) çeşitlerinden elde edilmiştir (Çizelge 4). Araştırmamızda elde edilen sonuçlar diğer araştırıcıların değerleri ile karşılaştırıldığında, protein oranın \%11.2-13.4 değişimini bulan Öztürk ve ark. (1997) ile yakınlık gösterirken, \%10.8-11.5 arasında değiştiğini belirten Engin (2005) ve \%10.40-11.50 arasında değiştiğini belirten Taş ve Yürür (2002)'ün değerlerinden daha yüksek saptanmıştır. Elgün ve ark. (2001), tahıllarda protein miktarının çeşit, çevre ve toprak faktörlerine göre değiştiğini belirtmektedir. Protein miktarına, iklim ve topraktaki alınabilir azot oranının önemli etkisi vardır. Topraktaki alınabilir azot oranı arttıkça tanedeki protein miktarı da yükselmektedir. Yemlik arpada protein oranının \%12'nin üzerinde olması gerekir (Elgün ve ark., 2001; Kün, 1996; Çölkesen, 1993). Araştırma sonucunda en yüksek proteine sahip olan Akhisar-98 (\%15.65), Epona (\%15.61), Martı (\%15.27) ve Avcı-2002 (\%15.26) çeşitlerinin yemlik özelliğe sahip olduğu açıklanabilir.

\section{Yağ Oranı}

Araştırmada kullanılan çeşitlerin yağ oranına ilişkin varyans analiz sonuçları Çizelge 3'de verilirken, çeşitlere ait ortalama değerler ise Çizelge $5^{\prime}$ te verilmiştir. ỉki yılın ortalamasına göre yağ oranı \%1.36-2.01 arasında değişmiştir. Yılların ve çeşitlerin ortalamasına göre yağ oranının \% 1.73 olduğu bulunmuş, en yüksek yağ oranına sırasıyla Çetin2000 (\%2.01), Vamıkhoca-98 (\%1.93) ve Erginel-90 (\%1.90) çeşitleri sahip olmuştur (Çizelge 5). Brand ve ark. (2003), tahıllarda yağ oranının \%2.1 ile 2.3 arasında değişim gösterdiğini belirtirken; Rakha ve ark. (2013), \%1.13 ile 1.17 arasında değiştiğini bildirmişlerdir. Araştırmacılar, yağ oranının arpa çeşidine, iklim şartlarına ve yetiştirme tekniğine bağlı olarak değiştiğini bildirmişlerdir (Campell ve ark., 1995; Grausgruber ve ark., 2000; Ereifej ve ark., 2007; Barteczko ve ark., 2009). 


\section{Nişasta Içeriği}

Nişasta içeriğine ait ortalamalar $\mathrm{P} \leq 0.01$ düzeyinde önemli bulunmuştur (Çizelge 3). İki yılın ortalamasına göre nişasta içeriği \%52.61-58.60 arasında değiş̧iştir. Yılların ve çeşitlerin ortalaması olarak, nişasta oranının \%55.26 olduğu saptanmış; en yüksek nişasta içeriğine Olgun (\%58.60) ve Lord (\%57.82) çeşitleri sahip olmuştur. En düşük nişasta içeriği ise, Kıral-97 (\%52.61) çeşidinden elde edilmiştir (Çizelge 5). Arpa tanesinin bileşenleri arasında yoğunluğu en fazla olan nişastadır. Dolayısıyla hektolitre ağırlığı arpa tanesinin daha fazla nişasta ve malt ekstrakt oranına sahip olduğu anlamına gelmektedir (İmamoğlu ve ark., 2016). Arpalarda nişasta oranı yükseldikçe protein oranının düştüğü (Kün,1996), araştırmamızda tespit edilmiştir. Tahıllar üzerinde yapılan çalışmalarda nişasta içeriğinin, Brand ve ark. (2003) tarafından \%59.8 ile 63.6; Rakha ve ark. (2013) tarafından \%63.5 ile 70.4; Kızılgeçi ve Yıldırım (2017) tarafından \% 62.5 ile 64.7 arasında değiştiği bildirilmiştir. Farklı araştııııların yaptıkları çalışmalarda, nişasta içeriğinin çeşitlere ve yetiştirme koşullarına göre değiştiği bildirilmiştir (Campell ve ark., 1995; Grausgruber ve ark., 2000; Koca ve ark., 2011; Mahla ve ark., 2015).

Çizelge 3. Denemeye alınan 11 altı sıralı arpa çeşidinin nem, kül, protein, yağ ve nişasta içeriklerine ilişkin varyans analiz sonuçları.

Table 3. Variance analysis results regarding the moisture, ash, crude protein, oil and starch contents of 11 six rows of barley varieties.

\begin{tabular}{|c|c|c|c|c|c|c|}
\hline \multirow[b]{2}{*}{$\begin{array}{l}\text { Varyasyon } \\
\text { Kaynakları }\end{array}$} & \multirow{2}{*}{$\begin{array}{l}\text { Serbestlik } \\
\text { Derecesi } \\
\text { (SD) }\end{array}$} & \multicolumn{5}{|c|}{ Kareler ortalaması } \\
\hline & & $\begin{array}{l}\text { Nem oranı } \\
\text { (\%) }\end{array}$ & $\begin{array}{l}\text { Kül oranı } \\
\text { (\%) }\end{array}$ & $\begin{array}{l}\text { Protein oranı } \\
\text { (\%) }\end{array}$ & $\begin{array}{l}\text { Yağ oranı } \\
\text { (\%) }\end{array}$ & $\begin{array}{l}\text { Nişasta içeriği } \\
\text { (\%) }\end{array}$ \\
\hline YII & 1 & 0.013 & $0.330^{* *}$ & $1.288^{*}$ & $0.059^{*}$ & $64.194^{\star *}$ \\
\hline Çeşit & 10 & $0.343^{\star *}$ & $0.060 * *$ & $7.167^{\star \star}$ & $0.262^{* *}$ & $18.623^{\star *}$ \\
\hline Yıl x Çeşit & 10 & $0.055^{\star *}$ & 0.013 & 0.136 & 0.013 & 1.545 \\
\hline Tekrar & 4 & 0.458 & 0.141 & 1.373 & 0.181 & 27.901 \\
\hline Hata & 40 & 0.0196 & 0.017 & 0.232 & 0.014 & 2.411 \\
\hline Genel & 65 & & & & & \\
\hline \multicolumn{2}{|c|}{ Değişim katsayısı (\%) } & 1.47 & 6.06 & 3.34 & 6.83 & 2.81 \\
\hline
\end{tabular}

Çizelge 4. Denemede kullanılan arpa çeşitlerinin nem, kül ve protein içeriklerine ilişkin ortalama değerler. Table 4. Average values of moisture, ash and raw protein content of barley varieties used in the experiment.

\begin{tabular}{|c|c|c|c|c|c|c|c|c|c|}
\hline \multirow{2}{*}{ ÇEŞiTLER } & \multicolumn{3}{|c|}{ Nem oranı (\%) } & \multicolumn{3}{|c|}{ Kül oranı (\%) } & \multicolumn{3}{|c|}{ Protein oranı (\%) } \\
\hline & 2012-13 & 2013-14 & Ortalama & 2012-13 & 2013-14 & Ortalama & 2012-13 & 2013-14 & Ortalama \\
\hline Erginel-90 & 9.34 hij & 9.22 ijk & $9.28 \mathrm{~d}$ & 2.04 & 2.19 & $2.12 c-f$ & 13.67 & 13.94 & $13.80 \mathrm{~cd}$ \\
\hline Meriç & $9.54 \mathrm{~d}-\mathrm{h}$ & $9.63 c-g$ & $9.58 \mathrm{c}$ & 2.03 & 2.11 & 2.07 def & 14.48 & 15.16 & $14.82 \mathrm{~b}$ \\
\hline Kıral-97 & $9.40 \mathrm{~g}-\mathrm{j}$ & $9.02 \mathrm{k}$ & $9.21 \mathrm{~d}$ & 2.15 & 2.47 & $2.31 a^{* \star}$ & 12.51 & 13.05 & $12.78 \mathrm{e}$ \\
\hline Çetin-2000 & 9.35 hij & $9.20 \mathrm{jk}$ & $9.27 \mathrm{~d}$ & 2.09 & 2.17 & $2.13 b-f$ & 13.39 & 13.41 & $13.40 \mathrm{~d}$ \\
\hline Avcl-2002 & 9.34 hij & $9.18 \mathrm{jk}$ & $9.26 \mathrm{~d}$ & 2.09 & 2.35 & $2.20 \mathrm{a}-\mathrm{d}$ & 15.03 & 15.49 & $15.26 \mathrm{ab}$ \\
\hline Martı & $9.84 a b c$ & $9.92 \mathrm{ab}$ & $9.88 a^{* \star}$ & 2.19 & 2.35 & $2.27 \mathrm{ab}$ & 15.12 & 15.42 & $15.27 \mathrm{ab}$ \\
\hline Vamıkhoca-98 & 9.44 e-h & 9.49 e-h & $9.46 \mathrm{c}$ & 2.21 & 2.30 & $2.24 a b c$ & 14.97 & 14.98 & $14.97 \mathrm{~b}$ \\
\hline Akhisar-98 & $9.67 c-f$ & $9.93 a^{* *}$ & $9.80 \mathrm{a}$ & 2.12 & 2.22 & 2.17 a-e & 15.42 & 15.88 & $15.65 a^{* *}$ \\
\hline Lord & 9.50 e-h & 9.74 a-d & $9.63 \mathrm{bc}$ & 2.00 & 2.03 & 2.02 ef & 13.98 & 14.01 & $13.99 c$ \\
\hline Epona & $9.66 c-f$ & $9.55 \mathrm{~d}-\mathrm{h}$ & $9.60 \mathrm{bc}$ & 2.03 & 2.30 & 2.17 a-e & 15.32 & 15.90 & $15.61 \mathrm{a}$ \\
\hline Olgun & $9.81 \mathrm{abc}$ & $9.70 \mathrm{~b}-\mathrm{e}$ & $9.76 \mathrm{ab}$ & 1.96 & 2.04 & $2.00 \mathrm{f}$ & 12.87 & 12.58 & $12.73 \mathrm{e}$ \\
\hline \multirow[t]{2}{*}{ Ortalama } & 9.54 & 9.51 & 9.52 & $2.08 \mathrm{~b}$ & $2.23 a^{* *}$ & 2.16 & $14.25 \mathrm{~b}$ & $14.53 a^{*}$ & 14.39 \\
\hline & \multicolumn{3}{|c|}{ LSD çeşit: 0.16 yıl x çeşit: 0.23} & \multicolumn{3}{|c|}{ LSD çeşit: 0.15} & \multicolumn{3}{|c|}{ LSD çeşit: 0.56} \\
\hline
\end{tabular}

Aynı harf ile gösterilen ortalamalar arasında ${ }^{*} \mathrm{P}<0.05,{ }^{* *} \mathrm{P}<0.01$ olasılıkla fark yoktur.

\section{Asit Deterjanda Çözünmeyen Lif (ADF)}

Asit deterjanda çözünmeyen lif (ADF), bitki hücre duvarı yapısındaki selüloz, lignin ve çözünmeyen protein miktarını göstermekte, ayrıca yemin sindirilebilirliği ve hayvanın enerji alımı hakkında da bilgi vermektedir. Yüksek asit deterjanda çözünmeyen lif içeren yemlerin sindirilebilirliği ve enerji değeri düşüktür (Kutlu, 2008). Birleştirilmiş varyans analizine göre genotiplerin ADF değeri açısından çeşitler arasındaki farkın istatistiksel olarak çok önemli $(P<0.01)$ bulunmuştur (Çizelge 6). Denemeye alınan arpa çeşitlerinin asit deterjanda çözünmeyen lif (ADF) değerine ait ortalama veriler Çizelge 7'de gösterilmiştir. Çizelge 7'den görüleceği üzere, yılların ortalamasına göre çeşitlerin ADF değerleri \%5.52-8.65 arasında değişmektedir. En yüksek ADF değeri \%8.65 ile Kıral-97 çeşidinden elde edilirken, en düşük ADF değer ise \%5.52 ile Meriç çeşidinden elde edilmiş, bu çeşidi Lord (\%5.82), Avcı-2002 (\%5.90) ve Epona (\%5.99) çeşitleri izlemiştir. Han ve ark. (2003), yaptıkları çalışmada üç arpa hattına ait tanelerin ADF değerlerinin \%7,52 ile \%7,91 arasında değiştiğini bulmuşlardır. Yapılan diğer çalışmalarda ADF miktarının, 
\%3.6 ile 4.1 (Brand ve ark., 2003); \%2.5 ile 3.1 (Rakha ve ark., 2013); \%7.03 ile 9.07 (Alkan ve Kandemir, 2015); \%2.5 ile 2.9 (Alijosius ve ark., 2016), \%1.43 ile 3.47 (Erbaş Köse ve Mut, 2019) arasında değiştiği bildirilmiştir. Farklı araştırmacılar tarafından yapılan çalışmalarda ADF değerinin çeşitlere ve yıllara göre farklılık gösterdiği belirlenmiştir (Brand ve ark., 2003; Barteczko ve ark., 2009; Can ve Ayan, 2017; Mut ve ark., 2017).

Çizelge 5. Denemede kullanılan arpa çeşitlerinin yağ oranı ve nişasta içeriğine ilişkin ortalama değerler. Table 5. Average values of oil content and starch content of barley varieties used in the experiment.

\begin{tabular}{|c|c|c|c|c|c|c|}
\hline \multirow{2}{*}{ ÇEŞiTLER } & \multicolumn{3}{|c|}{ Yağ oranı (\%) } & \multicolumn{3}{|c|}{ Nişasta içeriği (\%) } \\
\hline & 2012-13 & 2013-14 & Ortalama & 2012-13 & 2013-14 & Ortalama \\
\hline Erginel-90 & 1.97 & 1.82 & $1.90 \mathrm{abc}$ & 56.42 & 54.26 & $55.34 \mathrm{~cd}$ \\
\hline Meriç & 1.87 & 1.65 & $1.76 \mathrm{cde}$ & 57.03 & 55.10 & $56.06 \mathrm{bc}$ \\
\hline Kıral-97 & 1.56 & 1.64 & $1.60 \mathrm{f}$ & 54.60 & 50.62 & $52.61 \mathrm{e}$ \\
\hline Çetin-2000 & 2.04 & 1.98 & $2.01 a^{* *}$ & 57.01 & 54.50 & $55.75 \mathrm{c}$ \\
\hline Avcl-2002 & 1.71 & 1.65 & 1.68 ef & 54.90 & 52.44 & $53.67 \mathrm{de}$ \\
\hline Martı & 1.82 & 1.85 & $1.84 \mathrm{bcd}$ & 55.60 & 53.75 & $54.67 \mathrm{~cd}$ \\
\hline Vamıkhoca-98 & 1.92 & 1.94 & $1.93 a b$ & 55.60 & 53.53 & $54.56 \mathrm{~cd}$ \\
\hline Akhisar-98 & 1.48 & 1.33 & $1.41 \mathrm{~g}$ & 54.60 & 53.21 & $53.90 \mathrm{de}$ \\
\hline Lord & 1.90 & 1.80 & $1.85 \mathrm{bcd}$ & 58.07 & 57.57 & $57.82 \mathrm{ab}$ \\
\hline Epona & 1.40 & 1.32 & $1.36 \mathrm{~g}$ & 56.08 & 53.52 & $54.80 \mathrm{~cd}$ \\
\hline Olgun & 1.71 & 1.74 & 1.72 def & 58.75 & 58.46 & $58.60 a^{* *}$ \\
\hline \multirow[t]{2}{*}{ Ortalama } & $1.76 a^{*}$ & $1.70 b$ & 1.73 & $56.24 a^{* *}$ & $54.27 b$ & 55.26 \\
\hline & \multicolumn{3}{|c|}{ LSD çeşit: 0.14} & \multicolumn{3}{|c|}{ LSD çeşit: 1.81} \\
\hline
\end{tabular}

Aynı harf ile gösterilen ortalamalar arasında ${ }^{*} \mathrm{P}<0.05,{ }^{* *} \mathrm{P}<0.01$ olasılıkla fark yoktur.

Çizelge 6. Denemeye alınan 11 altı sıralı arpa çeşidinde ADF, NDF, K, Mg ve P içeriğine ilişkin varyans analiz sonuçları. Table 6. Variance analysis results for $A D F, N D F, K, M g$ and $P$ content in 11 six-row barley varieties included in the trial.

\begin{tabular}{|c|c|c|c|c|c|c|}
\hline \multirow[b]{2}{*}{$\begin{array}{l}\text { Varyasyon } \\
\text { Kaynakları }\end{array}$} & \multirow{2}{*}{$\begin{array}{c}\text { Serbestlik } \\
\text { Derecesi } \\
\text { (SD) }\end{array}$} & \multicolumn{5}{|c|}{ Kareler Ortalaması } \\
\hline & & ADF (\%) & NDF (\%) & K (\%) & Mg (\%) & $\mathbf{P}(\%)$ \\
\hline Yıl & 1 & $3.908^{* *}$ & $13.342^{* *}$ & $0.01440 * *$ & 0.00014 & 0.00027 \\
\hline Çeşit & 10 & $4.409 * *$ & $9.690 * *$ & $0.00597^{* *}$ & $0.00034^{* *}$ & $0.00045^{* *}$ \\
\hline Yıl x Çeşit & 10 & 0.213 & 0.368 & 0.00104 & 0.000022 & 0.000041 \\
\hline Tekrar & 4 & 2.793 & 5.437 & 0.01757 & 0.00022 & 0.00044 \\
\hline Hata & 40 & 0.259 & 0.509 & 0.00165 & 0.000039 & 0.000088 \\
\hline Genel & 65 & & & & & \\
\hline \multicolumn{2}{|c|}{ Değişim Katsayısı (\%) } & 7.67 & 3.20 & 5.413 & 3.335 & 2.152 \\
\hline
\end{tabular}

Çizelge 7. Denemede kullanılan arpa çeşitlerinin ADF ve NDF değerlerine ilişkin ortalama değerler. Table 7. Average values of ADF and NDF values of barley varieties used in the experiment.

\begin{tabular}{|c|c|c|c|c|c|c|}
\hline \multirow{2}{*}{ ÇEŞiTLER } & \multicolumn{3}{|c|}{ ADF (\%) } & \multicolumn{3}{|c|}{ NDF (\%) } \\
\hline & 2012-13 & 2013-14 & Ortalama & 2012-13 & 2013-14 & Ortalama \\
\hline Erginel-90 & 6.33 & 6.93 & $6.63 \mathrm{~b}$ & 21.68 & 22.81 & $22.25 \mathrm{~cd}$ \\
\hline Meriç & 5.51 & 5.52 & $5.52 \mathrm{c}$ & 20.22 & 20.96 & 20.59 e \\
\hline Kıral-97 & 8.10 & 9.20 & $8.65 a^{* *}$ & 24.08 & 25.97 & $25.03 a^{* *}$ \\
\hline Çetin-2000 & 6.59 & 7.31 & $6.95 \mathrm{~b}$ & 22.03 & 23.10 & $22.57 \mathrm{c}$ \\
\hline Avcl-2002 & 5.47 & 6.32 & $5.90 \mathrm{C}$ & 20.85 & 22.31 & $21.58 d$ \\
\hline Martı & 6.64 & 7.13 & $6.89 \mathrm{~b}$ & 22.21 & 22.93 & $22.57 \mathrm{C}$ \\
\hline Vamıkhoca-98 & 6.73 & 6.88 & $6.81 \mathrm{~b}$ & 22.42 & 22.70 & $22.56 \mathrm{c}$ \\
\hline Akhisar-98 & 6.76 & 6.65 & $6.71 \mathrm{~b}$ & 23.39 & 23.66 & $23.53 b$ \\
\hline Lord & 5.72 & 5.93 & $5.82 \mathrm{c}$ & 20.19 & 20.65 & $20.42 \mathrm{e}$ \\
\hline Epona & 5.69 & 6.28 & $5.99 \mathrm{c}$ & 21.60 & 22.65 & $22.13 \mathrm{~cd}$ \\
\hline Olgun & 6.72 & 7.46 & $7.09 \mathrm{~b}$ & 21.81 & 22.63 & $22.22 \mathrm{~cd}$ \\
\hline \multirow[t]{2}{*}{ Ortalama } & $6.39 b$ & $6.87 a^{* *}$ & 6.63 & $21.86 \mathrm{~b}$ & $22.76 a^{\star \star}$ & 22.31 \\
\hline & \multicolumn{3}{|c|}{ LSD çeşit: 0.59} & LSD çeşit: C & & \\
\hline
\end{tabular}

Aynı harf ile gösterilen ortalamalar arasında ${ }^{*} \mathrm{P}<0.05,{ }^{* *} \mathrm{P}<0.01$ olasılıkla fark yoktur.

\section{Nötr Deterjanda Çözünmeyen Lif (NDF)}

Bitki hücre duvarı yapısında bulunan selüloz, hemiselüloz, lignin, kütin ve çözünmeyen protein miktarı NDF (Nötr deterjanda çözünmeyen lif) olarak ifade edilmektedir. Nötr deterjanda çözünmeyen lif (NDF) değeri 
hayvanların beslenmesinde (yem) doğrudan etkili olup, yem içeriğindeki bu değer azaldıkça hayvanın beslenmesi daha artmaktadır (Van Soest ve ark., 1991, Mut ve ark., 2017). Bu yüzden, NDF oranının düşük olması, hayvan besleme açısından istenen bir parametredir. Bu araştırmada, nötr deterjanda çözünmeyen lif (NDF) değerine ait ortalamalar istatistiksel olarak $P \leq 0.01$ seviyesinde farklılık göstermiş (Çizelge 6) ve yılların ortalamasına göre en çok NDF değeri \%25.03 ile Kıral-97, en az NDF değeri ise Lord (\%20.42) ve Meriç (\%20.59) çeşitlerinden elde edilmiştir (Çizelge 7). Yapılan çalışmalarda, NDF değerinin \%17.6 ile 21.1 (Brand ve ark., 2003), \%8.0 ile 14.8 (Rakha ve ark., 2013), \%20.46 ile 26.61 (Alkan ve Kandemir 2015), \%10.3 ile 13.1 (Alijosius ve ark., 2016), \%22.00 ile 25.33 (Erbaş Köse ve Mut 2019) arasında değiştiği bildirilmiştir. Fox ve ark. (2003)'nın yaptıkları çalışmada, arpanın NDF değerinin \%15-30 arasında değiştiği rapor edilmiştir. Fife ve ark. (2008)'nın yaptıkları çalışmada ise, arpa tanesinin NDF içeriğinin \%19,9 ile \%24,5 arasında değiştiğini bildirmişlerdir. Farklı Araştırmacılar yaptıkları çalışmalarda, NDF değerlerinin çeşitlere ve yıllara göre farklılık gösterdiğini bildirmişlerdir (Campell ve ark., 1995; Brand ve ark., 2003; Barteczko ve ark., 2009; Can ve Ayan, 2017; Mut ve ark., 2017).

Çizelge 8. Denemede kullanılan arpa çeşitlerinin $\mathrm{K}, \mathrm{Mg}$ ve $\mathrm{P}$ içeriklerine ilişkin ortalama değerler. Table 8. Average values of $K, \mathrm{Mg}$ and $\mathrm{P}$ contents of barley varieties used in the experiment.

\begin{tabular}{|c|c|c|c|c|c|c|c|c|c|}
\hline \multirow{2}{*}{ ÇEŞiTLER } & \multicolumn{3}{|c|}{ K (\%) } & \multicolumn{3}{|c|}{ Mg (\%) } & \multicolumn{3}{|c|}{ P (\%) } \\
\hline & 2012-13 & 2013-14 & Ortalama & 2012-13 & 2013-14 & Ortalama & 2012-13 & 2013-14 & Ortalama \\
\hline Erginel-90 & 0.701 & 0.738 & $0.720 \mathrm{~cd}$ & 0.181 & 0.186 & $0.183 \mathrm{cde}$ & 0.433 & 0.435 & $0.434 \mathrm{~cd}$ \\
\hline Meriç & 0.748 & 0.762 & $0.755 \mathrm{abc}$ & 0.182 & 0.186 & $0.184 \mathrm{~cd}$ & 0.433 & 0.433 & $0.433 \mathrm{~cd}$ \\
\hline Kıral-97 & 0.706 & 0.767 & $0.736 \mathrm{bc}$ & 0.177 & 0.185 & $0.181 \mathrm{def}$ & 0.421 & 0.432 & $0.426 d$ \\
\hline Çetin-2000 & 0.712 & 0.716 & $0.714 \mathrm{~cd}$ & 0.183 & 0.184 & $0.184 \mathrm{~cd}$ & 0.435 & 0.433 & $0.434 \mathrm{~cd}$ \\
\hline Avcl-2002 & 0.722 & 0.789 & $0.756 a b c$ & 0.184 & 0.193 & $0.189 \mathrm{bc}$ & 0.432 & 0.444 & 0.438 bc \\
\hline Martı & 0.789 & 0.806 & $0.798 a^{\star *}$ & 0.197 & 0.201 & $0.199 a^{\star *}$ & 0.447 & 0.452 & $0.450 a^{* *}$ \\
\hline Vamıkhoca-98 & 0.776 & 0.775 & $0.775 a b$ & 0.193 & 0.190 & $0.192 b$ & 0.447 & 0.446 & $0.446 a b$ \\
\hline Akhisar-98 & 0.723 & 0.743 & $0.733 \mathrm{bcd}$ & 0.194 & 0.197 & $0.196 a b$ & 0.447 & 0.448 & $0.448 a b$ \\
\hline Lord & 0.728 & 0.735 & $0.732 \mathrm{bcd}$ & 0.176 & 0.177 & 0.176 ef & 0.426 & 0.425 & $0.425 d$ \\
\hline Epona & 0.736 & 0.808 & $0.772 \mathrm{ab}$ & 0.190 & 0.190 & $0.190 \mathrm{bc}$ & 0.434 & 0.445 & $0.439 a b c$ \\
\hline Olgun & 0.675 & 0.699 & $0.687 \mathrm{~d}$ & 0.176 & 0.175 & $0.175 \mathrm{f}$ & 0.423 & 0.430 & $0.427 \mathrm{~d}$ \\
\hline \multirow[t]{2}{*}{ Ortalama } & $0.729 b$ & $0.758 a^{* *}$ & 0.743 & 0.185 & 0.188 & 0.186 & 0.434 & 0.438 & 0.436 \\
\hline & \multicolumn{3}{|c|}{ LSD çeşit: 0.047} & \multicolumn{3}{|c|}{ LSD çeşit: 0.0073} & \multicolumn{3}{|c|}{ LSD çeşit: 0.0195} \\
\hline
\end{tabular}

Aynı harf ile gösterilen ortalamalar arasında ${ }^{*}<<0.05,{ }^{* *} \mathrm{P}<0.01$ olasılıkla fark yoktur.

\section{Potasyum (K)}

Bitkiler fazla miktarda potasyuma intiyaç duyarlar. Potasyum sitoplazmada en çok bulunan katyondur. Fotosentezin gerçekleşmesinde, enzim aktivitesinde ve bitkilerin su içeriklerinin düzenlenmesinde önemli görevleri vardır. Bu nedenlerden dolayı, potasyum sadece yetiştirme ve verim için değil aynı zamanda tahılların şeker ve protein içerikleri açısından da önemlidir (Kaçar ve Katkat, 1998; Güneş ve ark., 2000). Çalışmamızda incelenen çeşitler arasında potasyum değeri bakımından 2 yılın ortalamasında en yüksek değer, Martı (\%0.798) çeşidinde saptanmıştır. Bu çeşidi Vamıkhoca-98 (\%0.775), Epona (\%0.772), Avcı-2002 (\%0.756) ve Meriç (\%0.755) çeşitleri izlemiştir. Çeşitler arasındaki en düşük potasyum değeri ise Olgun çeşidinde \%0.687 olarak belirlenmiştir. Yapılan çalışmada potasyum değeri \%0.525 ile 0.668 (Mut ve Erbaş Köse, 2018), potasyum içeriğinin $2200 \mathrm{mg} \mathrm{kg}$ 1 ile $4800 \mathrm{mg} \mathrm{kg}^{-1}$ (Villacres ve Rivadeneira, 2005) arasında değiştiği bildirilmiştir. Stewart ve ark. (1988) yaptıkları çalışmada, tanede en yüksek miktarda potasyumun bulunduğunu ve toplam mikro element miktarının yaklaşık \%45'ini bu elementin oluşturduğunu bildirmektedirler. Daha önceki yıllarda yapılan çalışmalarda da, potasyum (K) değerlerinin çeşitlere göre farklılık gösterdiği bildirilmiştir (Pena, 2004; Poutanen, 2012).

\section{Magnezyum (Mg)}

Magnezyum içeriklerine ait ortalamalar $P \leq 0.01$ seviyesinde önemli bulunmuştur (Çizelge 6). İki yılın ortalamasına göre magnezyum içerikleri \%0.175-0.199 arasında değişmiştir (Çizelge 8). Magnezyum içerikleri bakımından incelendiğinde en yüksek magnezyum değerine Martı (\%0.199) çeşidi sahip olmuş, bunu Akhisar-98 (\%0.196) çeşidi takip etmiştir (Çizelge 8). Denemeye alınan çeşitler arasında en düşük magnezyum değerine sahip çeşit Olgun (\%0.175) olmuştur. Yapılan çalışmalarda, magnezyum değerinin \%0.129 ile 0.150 (Mut ve Erbaş Köse, 2018), $1200 \mathrm{mg} \mathrm{kg}^{-1}$ ile $1600 \mathrm{mg} \mathrm{kg}^{-1}$ (Alkan ve Kandemir, 2015) arasında değiştiği bildirilmiştir. Daha önceki yıllarda yapılan çalışmalarda, Mg değerlerinin çeşitlere göre farklılık gösterdiği birçok araştırıcı tarafından bildirilmiştir (Myer ve Lozano, 2004; Jakobsone ve ark., 2015). 


\section{Fosfor (P)}

Birleştirilmiş varyans analizine göre genotiplerin fosfor değeri bakımından çeşitler arasındaki farkın istatistiksel olarak çok önemli $(P<0.01)$ olduğu saptanmıştır (Çizelge 6$)$. Denemeye alınan çeşitlerin fosfor değerine ilişkin ortalama değerler Çizelge 8'de verilmiştir. Çizelge 8'de fosfor değerleri incelendiğinde iki yılın ortalamasında en yüksek fosfor değeri Martı (\%0.450) çeşidinde belirlenmiştir. Bu çeşidi Akhisar-98 (\%0.448), Vamıkhoca-98 (\%0.446) ve Epona (\%0.439) çeşitleri takip etmiş ve istatistiksel olarak aynı grupta yer almışlardır. En düşük fosfor değeri Lord (\% 0.425), Kıral-97 (\%0.426) ve Olgun (\%0.427) çeşitlerinde tespit edilmiştir. Yapılan bir çalışmada, fosfor değerinin \%0.363 ile 0.408 (Mut ve Erbaş Köse, 2018) arasında değiştiği bildirilmiştir. Daha önceki yıllarda yapılan diğer çalışmalarda da, fosfor (P) değerlerinin çeşitlere göre farklılık gösterdiği bildirilmiştir (Pena, 2004; Myer ve Lozano, 2004; Poutanen, 2012; Jakobsone ve ark., 2015).

Araştırmada incelenen arpa çeşitlerinin bazı yemlik kalite özellikleri arasındaki ilişkiler Çizelge 9'de verilmiştir. Çizelge 9'de görüleceği üzere protein oranı ile kül oranı, $K, M g$ ve $P$ değerleri; kül oranı ile $A D F, N D F, K, M g$ ve $P$ değerleri; nişasta içeriği ile nem ve yağ oranı; $A D F$ il NDF ve $K$ değerleri; NDF ile $K, M g$ ve $P$ değerleri; $K$ ile $M g$ ve $P$ değerleri; Mg ile P değerleri arasında olumlu ve çok önemli ilişki görülmüştür. Ayrıca, protein oranı ile yağ oranı ve nişasta içeriği; kül oranı ile nem oranı ve nişasta içeriği; nem oranı ile ADF ve NDF; nişasta içeriği ile ADF ve NDF; yağ oranı ile NDF arasında ise olumsuz ve çok önemli ilişki belirlenmiştir. Protein ile ADF değeri; Nem oranı ile $\mathrm{K}$; yağ oranı ile $\mathrm{K}$ arasında olumsuz ve önemli ilişki görülmüştür. Ele alınan diğer karakterler arasında istatistiki olarak ilişki belirlenmemiştir (Çizelge 9). Campbell ve ark. (1995), protein oranı ile nişasta oranı ve yağ oranı arasında çok önemli ve olumsuz, protein oranı ile ADF ise olumsuz ve önemli ilişki olduğunu tespit etmişlerdir. Konu ile ilgili bazı diğer çalışmalarda da benzer sonuçlar elde edilmiştir (Akgün ve Altındal, 2011; Oral ve Ülker, 2016; Mut ve ark., 2017; Mut ve Erbaş Köse, 2018). Çölkesen ve ark. (1993) ve Öztürk ve ark. (1997), özellikle yüksek sıcaklıklar ve yetersiz yağış nedeni ile, kuru tarım bölgelerinde arpa kalitesinde önemli değişimler gözlendiğini belirtmişlerdir. Bundan dolayı, kalite özelliklerinin birbirleriyle olan ilişkileri iklimsel şartlara bağlı olarak değişim göstermektedir (Egesel ve ark., 2009; Mut ve ark., 2010).

Çizelge 9. Arpa çeşitlerinde incelenen özellikler arasındaki korelasyon katsayıları $(\mathrm{n}=88)$. Table 9. Correlation coefficients between the properties examined in barley varieties.

\begin{tabular}{lccccccccc}
\hline $\begin{array}{l}\text { Incelenen } \\
\text { karakterler }\end{array}$ & $\begin{array}{c}\text { Kül } \\
\text { oranı }\end{array}$ & $\begin{array}{c}\text { Protein } \\
\text { oranı }\end{array}$ & $\begin{array}{c}\text { Yağ } \\
\text { oranı }\end{array}$ & $\begin{array}{c}\text { Nişasta } \\
\text { içeriği }\end{array}$ & ADF & NDF & K & Mg & P \\
\hline Nem oranı & -0.4741 & 0.1251 & -0.1158 & 0.5354 & -0.4196 & -0.3640 & -0.2583 & 0.0355 & -0.1148 \\
& $* *$ & öd & öd & $* *$ & $* *$ & $* *$ & $*$ & $\begin{array}{c}\text { od } \\
\text { öd }\end{array}$ \\
Kül oranı & 1 & 0.4252 & -0.2160 & -0.9092 & 0.6625 & 0.7441 & 0.8414 & 0.6289 & 0.7314 \\
$* *$ \\
protein
\end{tabular}

** $0.01,{ }^{*} 0.05$ olasılıkla önemli. öd önemli değil.

\section{SONUÇ}

Doğu Karadeniz Bölgesi Gümüşhane ili Şiran ekolojik koşullarında çiftçi tarlasında 2012-13 ve 2013-14 yetiştirme dönemlerinde denemeye alınan 11 adet altı sıralı arpa çeşidi ile yürütülen çalışmadan elde edilen bazı yemlik kalite kriterlerine ilişkin veriler değerlendirilmiştir. Hayvan beslenmesi açısından arpada protein, yağ, nişasta ve mineral madde değerleri oldukça önemli olup, kalite açısından bu değerlerin yüksek olması yanında, sindirilme ve enerji değeri de yüksek olması arzulanmaktadır. Araştırmada, protein oranında Akhisar-98, Epona, Martı ve Avcı-2002 çeşitleri, yağ oranında Çetin-2000, Vamıkhoca-98 ve Erginel-90 çeşitleri, nişasta oranında 
Olgun ve Lord çeşitleri, mineral madde değerleri bakımından Martı, Vamıkhoca-98, Epona çeşitleri yemlik kalite yönüyle üstün bulunmuştur. Böylece bu çeşitler yemlik arpa üretimi yapan Doğu Karadeniz Bölgesi üreticilerine önerilebilir. Şüphesiz elde edilen bulgularımızın gerek çalışmamızda kullandığımız çeşitlere, gerek ekolojiye ve gerekse zamana ve bunların birbirleriyle etkileşimlerine bağlı oldukları unutulmamalı ve ulaşılan sonuçlar genelleştirilmemelidir.

\section{ÇIKAR ÇATIŞMASI}

Yazarlar arasında herhangi bir çıkar çatışması bulunmamaktadır.

\section{YAZAR KATKISI}

Abdulveli SIRAT: Makalenin çalışma konusu, yöntemi, arazi çalışmalarının yürütülmesi, laboratuvar analizleri ve makalenin yazılmasının gerçekleştirilmesi.

Bilge BAHAR: Arazi çalışmalarının yürütülmesi, İstatistik analizlerin yapılması ve makalenin yazılması.

\section{TEŞEKKÜR}

Bu çalışma Gümüşhane Üniversitesi Bilimsel Araştırma Projeleri Birimi (GÜBAP) tarafından desteklenmiştir (Proje No: 2012.02.M407.1).

\section{KAYNAKLAR}

Akgün, I., \& Altındal, D. (2011). Bazı tritikale genotiplerinde tane verimi ve stabilite analizi. Süleyman Demirel Üniversitesi Ziraat Fakültesi Dergisi, 6(1), 7-14.

Alijosius, S., Avirmickas, G. J., Bliznikas, S., Gruzauskas, R., Sasyte, V., Raceviciute-Stupeliene, A., Kliseviciute, V., \& Dauksiene, A. (2016). Grain chemical composition of different varieties of winter cereals. Zemdirbyste-Agriculture, 103(3), 273-280.

Alkan, F. R., \& Kandemir, N. (2015). Tokak yerel arpa çeşidi içinden seçilen saf hatların bazı gıda, yem ve tarımsal özellikler bakımından varyasyonları. Tarla Bitkileri Merkez Araştırma Enstitüsü Dergisi, 24(2), 124-139.

Anjum, M. I., Ghazanfar, S., \& Begum, I. (2014). Nutritional composition of wheat grains and straw influenced by differences in varieties grown under uniform agronomic practices. International Journal of Veterinary Science, 3(3), 100-104.

Barteczko, J., Augustyn, R., Lasek, O., \& Smulikowska, S. (2009). Chemical composition and nutritional value of different wheat cultivars for broiler chickens. Journal of Animal and Feed Sciences, 18, 124-131.

Bekele, B., Alemayehu, F., \& Lakew B. (2005). Food Barley Importance, Uses and Local Knowledge. International Center for Agricultural Research in the Dry Areas, ICARDA.

Brand, T. S., Cruywagen, C. W., Brandt, D. A., Viljoen, M., \& Burger, W. W. (2003). Variation in the chemical composition, physical characteristics and energy values of cereal grains produced in the western cape area of South Africa. South African Journal of Animal Science, 33(2), 117-126.

Campbell, L. D., Boila, R. J., \& Stothers, S. C. (1995). Variation in the chemical composition and test weight of barley and wheat grain grown at selected locations throughout Manitoba. Canadian Journal of Animal Science, 75(2), 239-246.

Can, M., \& Ayan, İ. (2017). Domuz ayrığı (Dactylis glomerata L.) popülasyonlarında gelişme dönemlerine göre verim ve bazı özelliklerin değişimi. Kahramanmaraş Sütçü Imam Üniversitesi Tarım ve Doğa Dergisi, 20(2), 160-166.

Çölkesen, M. (1993). Buğday ve arpada kalitenin belirlenmesi. Harran Üniversitesi Ziraat Fakültesi Dergisi, 4(1), 115-128.

Çölkesen, M., Yağbasanlar, T., Kırtok, Y., \& Kılıç, M. (1993). Çukurova ve Şanlıurfa koşullarına uygun arpa çeşitlerinin saptanması üzerine araştırma. Çukurova Üniversitesi Ziraat Fakültesi Dergisi, 4(1), 36-53.

Egesel, C. Ö., Kahrıman, F., Tayyar, Ş., \& Baytekin, H. (2009). Ekmeklik buğdayda un kalite özellikleri ile dane veriminin karşılıklı etkileşimleri ve uygun çeşit seçimi. Anadolu Journal Agriculture Science 24, 76-83.

Elgün, A., Türker, S., \& Bilgiçli, N. (2001). Tahıl ve Ürünlerinde Analitik Kalite Kontrolü. Selçuk Üniversitesi Ziraat Fakültesi Gıda Mühendisliği Bölümü, Yayın No: 2, Konya.

Engin, A. (2005). Adıyaman koşullarına uygun yüksek verimli ve kaliteli maltık arpa çeşitlerinin belirlenmesi. GAP IV. Tarım Kongresi, Şanlıurfa. 
Erbaş, Köse, Ö., \& Mut, Z. (2019). Grain yield and some quality traits of bread wheat cultivars. 3. International Conferance on Agriculture, Food, Veterrinery and Pharmacy Sciences, Trabzon.

Ereifej, K. I., Al-Karaki, G. N., \& Hammouri, M. K. (2007). Variability of some physico-chemical characteristics of wheat cultivars grown under arid and semiarid mediterranean conditions. Internatıonal Journal of Food Propertıes, 4(1), 91-101.

Fife T. E., Szasz J. I., Hunt PAS., C. W., \& Ahola J. A. (2008). Relationship between quality characteristics of barley grain and digestibility in feedlot steers. The Professional Animal Scientist, 24, 560-565.

Fox, G. P., Panozzo, J. C. F., Li, C. D., Lance, R. C. M., Inkerman, P. A., \& Henry, R. J. (2003). Molecular basis of barley quality. Australian Journal of Agricultural Research, 54, 1081-1101.

Grausgruber, H., Oberforster, M., Werteber, M., Ruckenbauer, P., \& Volmann, J. (2000). Stability of quality traits in austriangrown winter wheats. Field Crops Research, 66(3), 257- 267.

Guo, T. R., Zhang, G. P., Zhou, M. X., Wu, F. B., \& Chen, J. X. (2003). Genotypic difference in plant growth and mineral composition in barley under aluminum stres. Agricultural Sciences in China, 2(5), 494-501.

Güneş, A., Alpaslan, M., \& İnal, A. (2000). Bitki Besleme ve Gübreleme. Ankara Üniversitesi Ziraat Fakültesi, Yayın No:1514, Ankara.

Han, F., Ullrich, S. E., Romagosa, I., Clancy, J. A., Frooseth, J. A., \& Wesenberg, D. M. (2003). Quantitative genetic analysis of acid detergent fiber content in barley. Journal Cereal Science 38,167-172.

İmamoğlu, A., Pelit, S., Sarı, N., Büyükkileci, C., \& Yıldız, Ö. (2016). Ege Bölgesi sahil kuşağına uyumlu arpa (Hordeum vulgare L.) çeşit ve genotiplerinin verim ve bazı kalite özelliklerinin belirlenmesi. Tarla Bitkileri Merkez Araştırma Enstitüsü Dergisi, 25(Özel sayı-1), 141-145.

Jakobsone, I., Kantane, I., Zute, S., Jansone, I., \& Bartkevies, V. (2015). Macro-elements and trace elements in cereal grains cultived References in Latvia. Proceeding of the Latvian Academy of Science, Section B, 69, 152-157.

JMP 7.0.2. (2007). SAS Institute Inc., Cary, North Carolina 27513, USA.

Kaçar, B., \& Katkat, A. V. (1998). Bitki Besleme. Vipaş Yayınları, Yayın No: 127, Bursa.

Kızılgeçi, F., \& Yıldırım, M. (2017). Bazı tritikale (X Triticosecale Wittmack) genotiplerinin verim ve kalite özelliklerinin belirlenmesi. Türkiye Tarımsal Araştırmalar Dergisi, 4(1), 43-49.

Koca, Y. O., Dere, Ş., \& Erekul, O. (2011). İleri ekmeklik buğday hatlarında tane verimi ve bazı kalite özelliklerinin belirlenmesi. Anan Menderes Üniversitesi Ziraat Fakültesi Dergisi, 8(2), 15-22.

Kutlu, H. R. (2008). Yem Değerlendirme ve Analiz Yöntemleri. Çukurova Üniversitesi Ziraat Fakültesi Zootekni Bölümü, Ders Notu: 18, Adan.

Kün, E. (1996). Tahıllar-I (Serin Iklim Tahılları). Ankara Üniversitesi Ziraat Fakültesi, Yayın No: 1451, Ankara.

Mahla, R., Madan, S., Munjal, R., \& Hasija, R. J. (2015). Drought stress induced changes in quality and yield parameters and their association in wheat genotypes. Environment and Ecology, 33(4), 1639-1643.

Mut, Z., Gülümser, A., \& Sirat, A. (2010). Comparison of stability statistics for yield in barley (Hordeum vulgare L.). African Journal of Biotechnology, 9(11), 1610-1618.

Mut, Z., Erbaş Köse, Ö. D., \& Akay, H. (2017). Bazı ekmeklik buğday (Triticum aestivum L.) çeşitlerinin tane verimi ve kalite özelliklerinin belirlenmesi. Anadolu Tarım Bilimleri Dergisi, 32(1), 85-95.

Mut, Z., \& Erbaş Köse, Ö. D. (2018). Tritikale genotiplerinin tane verimi ve bazı kalite özellikleri. Anadolu Tarım Bilimleri Dergisi, 33, 47-57.

Myer, R. O., \& Lozano, A. J. (2004). Triticale in livestock production. In M. Mergoum (Eds), Triticale Improvement and Production (pp. 183-211). Rome, Italy: FAO.

Oral, E., \& Ülker, M. (2016). Tritikale (X Triticosecale Wittmack) çeşitlerinde özellikler arası ilişkiler ve path analizi. Iğdır Üniversitesi Fen Bilimleri Enstitüsü Dergisi, 6(3), 153-160.

Özer, M. S., Özkan, H., Kola, H., \& Kaya, C. (2003). Çukurova Üniversitesi Ziraat Fakültesi Tarla Bitkileri Bölümü tarafından yetiştirilen bazı ekmeklik buğday ve tritikale çeşit ve hatları ile bölgemiz çiftçilerince üretilen ticari buğday çeşitlerinin fiziksel, kimyasal ve teknolojik özelliklerinin belirlenmesi. Gıda, 28(3), 251-257.

Öztürk, A., Çağlar, Ö., \& Akten, Ş. (1997). Erzurum yöresinde maltlık olarak yetiştirilebilecek arpa genotiplerinin belirlenmesi. Türkiye II. Tarla Bitkileri Kongresi, Samsun.

Öztürk, A., \& Aydın, F. (2004). Effect of water stress at various growth stages on some quality characteristics of winter wheat. Journal of Agronomy and Crop Science, 190, 93-99. 
Pena, R. J. (2004). Food uses of triticale. In M. Mergoum \& H. Go'mez-Macpherson (Eds.), Triticale improvement and production (pp. 37-48). Food and Agriculture Organization of United Nations, Rome.

Poutanen, K. (2012). Past and future of cereal grains as food for health. Trends in Food Science and Technology, 25(2), 58-62.

Rakha, A., Aman, P., \& Andersson, R. (2013). Rheological characterisation of aqueous extracts of triticale grains and its relation to dietary fibre characteristics. Journal of Agronomy and Crop Science, 57, 230-236.

Sencar, Ö., Gökmen, S., Yıldırım, A., \& Kandemir, N. (1997). Tarla Bitkileri Üretimi. Gazi Osmanpaşa Üniversitesi Ziraat Fakültesi Yayın No:3, Tokat.

Stewart, A., Nield H., \& John, N. (1988). An investigation of mineral content of barley grains and seedlings. Plant Physiology, 86, 93-97.

Sönmez, F., \& Yılmaz, N. (2000). Azot ve fosforun arpa tanesinin bazı makro ve mikro besin maddesi içerikleri üzerine etkisi. Tarım Bilimleri Dergisi, 6(2), 65-75.

Taş, B., \& Yürür, N. (2002). Bursa ekolojik koşullarında bazı yabancı iki sıralı arpa (Hordeum velgare distichon) çeşitlerinin kimi verim ve kalite özelliklerinin incelenmesi. Uludağ Üniversitesi Ziraat Fakültesi Dergisi, 16, 117-127, Bursa.

Ünal, S. S. (1991). Hububat Teknolojisi. Ege Üniversitesi Mühendislik Fakültesi, Yayın No: 216, İzmir.

Van Soest, P. J., Robertson, J. B., \& Lewis, B. A. (1991). Methods for dietary fiber, neutral detergent fiber, and nonstarch polysaccharides in relation to animal nutrition. Journal Dairy Science, 74(10), 3583-3597.

Villacres, E., \& Rivadeneira, M. (2005). Barley in Ecuador: production, grain quality for consumption and perspectives for improvement. Pages 127-137 in: Food Barley Importance Uses and Local Knowledge: Proc. International Workshop on Food Barley Improvement, Jan. 2002. S. Grando and H. G. Macpherson, eds. ICARDA, Aleppo, Syria. 